\title{
STRATEGI DAN ASPEK KEBERHASILAN PROGRAM PEMBERDAYAAN MASYARAKAT LOKAL DALAM PENGELOLAAN DESA WISATA KERSIK
}

\author{
Asih Soenarih', Budi Sri Fitria Alhumaira 2 , Dita Aprilia S3, Dharma Saputra ${ }^{4}$ \\ 1 Officer CSR, PT. Pertamina Hulu Kalimantan Timur \\ ${ }^{2}$ Community Development Officer, PT. Pertamina Hulu Kalimantan Timur \\ ${ }^{3}$ Community Development Officer, PT. Pertamina Hulu Kalimantan Timur \\ ${ }^{4}$ Ast.Manager PT. Pertamina Hulu Kalimantan Timur \\ E-mail: asih.miko@phm.pertamina.com
}

\begin{abstract}
Kersik Tourism Village is an example of developing a community-based local tourism industry under the guidance of the CSR team of PT Pertamina Hulu East Kalimantan. Blue Kersik Beach is the main destination that is visited of many people. The problem in this area is the high level of abrasion, so far it has eroded $80 \%$ of the shoreline and has displaced residential areas. There are other problems such as household waste and beach visitor waste that have not been managed properly. This study used descriptive qualitative method. Informants in this study were determined by purposive sampling technique. A total of 9 informants were selected with different backgrounds. In-depth interviews are conducted periodically to find out the community's response to tourism development. The development strategy is formed in two empowerment programs. The mangrove cultivation program, in addition to successfully overcoming abrasion, is also a potential for educational tourism that can be developed to complement tourism options on the Blue Kersik Beach. The existence of a waste management program is also a solution to the waste problem in Kersik Village. Waste management will be encouraged as a medium for producing souvenir products that can be enjoyed by visitors. This empowerment program is not only a solution but also produces various development directions that support efforts to establish a better Kersik Tourism Village.
\end{abstract}

Keywords: Kersik Tourism Village, Mangrove Cultivation, Waste Management

\begin{abstract}
Abstrak
Desa Wisata Kersik merupakan salah satu contoh pengembangan industri pariwisata lokal berbasis komunitas di bawah binaan tim CSR PT Pertamina Hulu Kalimantan Timur. Pantai Biru Kersik ini menjadi destinasi utama yang banyak dikunjungi oleh masyarakat. Permasalahan di wilayah ini adalah tingkat abrasi yang cukup tinggi, hingga saat ini sudah menggerus habis $80 \%$ bibir pantai dan sempat menggusur pemukiman warga. Terdapat permasalahan lain seperti sampah rumah tangga maupun sampah pengunjung pantai yang belum terkelola dengan baik. Penelitian ini menggunakan metode deskriptif kualitatif. Informan dalam penelitian ini ditentukan dengan teknik purposive sampling. Sebanyak 9 informan dipilih dengan latar belakang yang berbeda-beda. Wawancara mendalam dilakukan secara berkala untuk mengetahui respon masyarakat terhadap pengembangan pariwisata. Strategi pengembangan dibentuk dalam dua program pemberdayaan. Program budidaya mangrove selain berhasil mengatasi abrasi juga menjadi potensi wisata edukasi yang dapat dikembangkan untuk melengkapi pilihan wisata di Pantai Biru Kersik. Keberadaan program pengelolaan sampah juga menjadi solusi dari permasalahan sampah di Desa Kersik. Pengelolaan sampah akan didorong sebagai media penghasil produk cindera mata yang dapat dinikmati oleh pengunjung. Program pemberdayaan ini selain bersifat solutif juga menghasilkan berbagai arahan pengembangan yang mendukung upaya pembentukan Desa Wisata Kersik yang lebih baik.
\end{abstract}

Kata Kunci: Desa Wisata Kersik, Budidaya Mangrove, Pengelolaan Sampah 
Learning Society: Jurnal CSR, Pendidikan dan Pemberdayaan Masyarakat

Jurnal Program Studi Pendidikan Masyarakat

Universitas Mulawarman

Vol. 2 No. 1, Juni 2021. Hal: 45 - 57

\section{Pendahuluan}

Keberadaan industri pariwisata banyak dimanfaatkan berbagai daerah untuk menjadi tumpuan perekonomiannya. Sektor yang saat ini banyak diminati masyarakat ini telah memberikan banyak keuntungan atau capaian di berbagai daerah bahkan dalam skala negara. Tidak sedikit negara yang memanfaatkan pariwisata sebagai sumber devisa utama wilayahnya. Kolaborasi beberapa elemen dalam industri pariwisata tidak hanya meningkatkan nilai jual lokasi pariwisata, namun juga dinilai mampu meningkatkan perekonomian masyarakat. Tentu hal ini tidak hanya terjadi dalam skala besar, dalam turunannya berbagai daerah di Indonesia pun juga memanfaatkan sektor industri pariwisata untuk meningkatkan pendapatan daerah. Keberadaan industri pariwisata di daerah pun didorong oleh pariwisata lokal yang biasanya diselenggarakan di tingkat desa dalam bentuk desa wisata. Disisi lain kegiatan pariwisata selalu menjadi kebutuhan masyarakat dan bersifat tidak terbatas. Kemajuan teknologi membuka akses kemudahan kepada seluruh masyarakat untuk mengakses kegiatan pariwisata. Hal ini menyebabkan kegiatan pariwisata semakin berkembang dan bervariasi dalam menawarkan kegiatan wisata.

Bentang alam Indonesia memiliki potensi pariwisata yang indah didukung dengan kondisi alamiah yang memukau memberikan modal tersendiri dalam pengembangan pengembangan industri pariwisata. Letak geografis, kekayaan flora dan fauna memberikan akses secara luas kepada seluruh pengelola pariwisata. Pada proses pengembangannya juga telah banyak konsep yang ditawarkan tergantung dari sisi mana arah, tujuan, keberpihakan subjek dalam melaksanakannya. Salah satu konsep yang banyak digunakan dalam pengembangan pariwisata berbasis masyarakat adalah Community Based Tourism (CBT). Konsep ini pada umumnya dikembangkan untuk skala kecil dan mencakup interaksi antara pengunjung dan pengelola, cocok digunakan untuk pengembangan pariwisata lokal. Community Based Tourism juga banyak digunakan sebagai acuan program pemberdayaan masyarakat di beberapa daerah. Menurut Asker (2010) terdapat beberapa hal yang dapat mendukung penerapan konsep Community Based Tourism (CBT) ini:

1. Tim pengelolaan $C B T$ harus memiliki sumber daya manusia yang memiliki skill dan termotivasi dalam memajukan wilayahnya.

2. Semua stakeholder CBT harus memahami aturan dan hukum yang berkaitan dengan pengembangan ligkungan dan mampu merespon dengan cepat terhadap setiap perubahan.

3. $C B T$ harus membangun media monitoring dan melakukan evaluasi untuk setiap proses pelaksanaannya.

Keberhasilan CBT juga dapat diketahui apabila pada praktiknya konsep ini mampu menguatkan dan melibatkan komunitas untuk mengelola pariwisata lokal secara berkelanjutan, terdapat transparansi pengelolaan antar sakeholder maupun 
Learning Society: Jurnal CSR, Pendidikan dan Pemberdayaan Masyarakat

Jurnal Program Studi Pendidikan Masyarakat

Universitas Mulawarman

Vol. 2 No. 1, Juni 2021. Hal: 45 - 57

masyarakat, serta mampu memperbaiki tingkat kesejahteraan masyarakat lokal khususnya mampu meningkatkan nilai sosial dan ekonomi.

Pada pelaksanaan teknisnya, pendekatan partisipasi banyak digunakan dalam proses pengembangan pariwisata berbasis $C B T$. Pendekatan ini diyakini mampu untuk mendorong masyarakat berpartisipasi secara aktif sejak dalam proses perencanaan, pelaksanaan dan evaluasi program. Pada prinsipnya dalam proses pemberdayaan masyarakat itu mereka harus mampu mendominasi setiap tahapan disamping beberapa faktor yang lain seperti jaringan dan juga modal. Meskipun keberadaan faktorfaktor tersebut penting namun subjek dan objek pertama dalam pendekatan ini adalah masyarakat. Penelitian terkait community based tourism telah banyak dilakukan sebelumnya, Rizkianto dan Topowijono (2018) melakukan penelitian dengan judul "Penerapan Konsep CBT Dalam Pengelolaan Daya Tarik Wisata Berkelanjutan" yang dilakukan di Desa Wisata Bangun, Kabupaten Trenggalek. Penelitian tersebut mengkaji konsep CBT dalam bentuk partisipasi masyarakat lokal, pembentukan kelembagaan desa wisata, pengelolaan daya tarik wisata berwawasan lingkungan, dan terciptanya kegiatan usaha masyarakat. Penelitian berfokus pada konsep CBT dalam pengelolaan Desa Wisata. Adapun penelitian ini menganalisis prinsip CBT dengan fokus prinsip sosial dan lingkungan. Aprilia (2020) melakukan penelitian dengan topik serupa dengan perbedaan variabel yang digunakan untuk melihat penerapan prinsip CBT pada homestay Balkondes Wanurejo. Hasil penelitian ini menunjukkan bahwa proses akan berjalan dengan baik jika didukung oleh partisipasi masyarakat, perubahan perilaku, dan pembagian peran yang adil antara pemangku kepentingan. Hambatan dalam prinsip tersebut ialah kurangnya pelatihan dan pendampingan secara profesional bagi pemilik homestay yang berdampak pada manajemen dan pemasaran. Pada prinsip lingkungan terdapat konservasi sumber daya alam yang meliputi pengelolaan sampah dan lingkungan hidup, pemanfaatan ruang dan optimalisasi sumber daya alam.

Desa Wisata Kersik, Kecamatan Marang Kayu, Kutai Kartanegara merupakan salah satu contoh pengembangan industri pariwisata lokal berbasis komunitas atau community based tourism di bawah binaan tim CSR PT Pertamina Hulu Kalimantan Timur. Desa wisata ini memiliki keunggulan Pantai Biru Kersik dengan pemandangan yang masih asri dan alami. Pantai Biru Kersik ini menjadi destinasi utama yang banyak dikunjungi oleh masyarakat dari dalam maupun luar daerah sekitarnya. Namun yang menjadi permasalahan di wilayah ini adalah tingkat abrasi yang cukup tinggi karena Pantai Biru Kersik berbatasan langsung dengan Selat Makasar yang memiliki ombak barat dan timur dengan skala besar. Ombak besar ini menyebabkan abrasi disepanjang pantai. hingga saat ini sudah menggerus habis $80 \%$ bibir pantai dan sempat menggusur pemukiman warga. Selain abrasi, terdapat permasalahan lain seperti sampah rumah tangga maupun sampah pengunjung pantai yang belum terkelola dengan baik. Masih 
Learning Society: Jurnal CSR, Pendidikan dan Pemberdayaan Masyarakat

Jurnal Program Studi Pendidikan Masyarakat

Universitas Mulawarman

Vol. 2 No. 1, Juni 2021. Hal: 45 - 57

banyak ditemui sampah berserakan yang berujung pada pembakaran sampah secara langsung.

Mewujudkan Desa Kersik sebagai salah satu destinasi wisata unggulan berbasis pemberdayaan masyarakat artinya mampu memberikan solusi dari berbagai macam permasalahan yang saat ini ditemukan. Terdapat beberapa program yang terbentuk guna memberikan solusi atas permasalahan yang terjadi serta mengembangkan industri pariwisata lokal secara bersamaan. Masyarakat setempat bekerja sama dengan tim CSR PT Pertamina Hulu Kalimantan Timur membentuk program penanaman mangrove serta pengelolaan sampah yang berintegrasi dengan kegiatan pariwisata setempat. Selain untuk mengatasi permasalahan abrasi dan sampah, program ini juga akan dikembangkan sebagai wisata edukasi yang dapat diakses oleh masyarakat luas. Program-program ini tentunya menjadi potensi yang dapat dikembangkan untuk menunjang kegiatan pariwisata di Desa Kersik. Pembentukan program binaan di atas telah disesuaikan dengan kebutuhan masyarakat meskipun masih dijumpai berbagai kendala lapangan sehingga diperlukan pelatihan dan pendampingan program secara intens. Selain itu program juga hadir untuk memberikan solusi dari permasalahan yang selama ini menghambat bahkan mengancam kegiatan pariwisata di Desa Kersik. Pengembangan program Desa Wisata Kersik tentunya akan memberikan dampak positif bagi masyarakat sekitar, khususnya dalam meningkatkan nilai ekonomi dan sosial mereka. Oleh sebab itu, penelitian ini bertujuan untuk mengetahui potensi agrowisata pesisir di Pantai Biru Kersik melalui identifikasi potensi program dan mengetahui aspek sosial ekonomi pemberdayaan masyarakat setempat.

\section{Metode Penelitian}

Penelitian ini menggunakan metode deskriptif kualitatif. Metode penelitian kualitatif merupakan proses penelitian yang menghasilkan data deskriptif dari orang dan perilaku yang diamati serta berupa tulisan dan lisan (Moleong, 2012). Metode tersebut digunakan dengan tujuan untuk mendapatkan data yang akurat terkait identifikasi potensi program dan aspek sosial ekonomi dari penerapan CBT terhadap lingkungan masyarakat sekitar. Informan dalam penelitian ini ditentukan dengan teknik purposive sampling. Teknik tersebut dilakukan dengan menentukan informan sesuai dengan kapasitas dan pengetahuan yang dimiliki. Sebanyak 9 informan dipilih dengan latar belakang yang berbeda-beda (pemerintah, kelompok masyarakat, dan swasta). Wawancara mendalam dengan informan dilakukan secara berkala sesuai kebutuhan data yang dibutuhkan. Observasi dan dokumentasi dilakukan untuk memperkuat dan melengkapi data yang didapat dari wawancara mendalam. Data yang diperoleh diolah dan disajikan dengan pendekatan deskriptif berupa narasi deskripstif, tabel, dan juga foto beberapa kegiatan. Selanjutnya, dilakukan triangulasi data dalam proses validasi data penelitian. Setelah data-data tersebut valid, analisis data dilakukan untuk memahami realitas program dan mengumpulkan data menjadi rangkaian yang 
Learning Society: Jurnal CSR, Pendidikan dan Pemberdayaan Masyarakat

Jurnal Program Studi Pendidikan Masyarakat

Universitas Mulawarman

Vol. 2 No. 1, Juni 2021. Hal: 45 - 57

sistematis. Tujuannya adalah untuk mengetahui respon masyarakat terhadap pengembangan industri pariwisata di daerahnya.

\section{Hasil Dan Pembahasan}

\section{Strategi Pengembangan Potensi Wisata di Desa Wisata Kersik}

$\begin{array}{ccc}\text { Pada dasarnya, } & \text { strategi } \\ \text { pengembangan } & \text { Desa Wisata Kersik }\end{array}$
mengarah pada pengembangan agrowisata pesisir yang berprinsip pada keberlangsungan pariwisata. Berdasarkan observasi yang telah dilakukan terdapat beberapa potensi daya tarik yang dapat mendukung pengembangan wisata di Desa Kersik khususnya yang berkaitan dengan kawasan pesisir. Menurut Utama (2012) agrowisata kawasan pesisir adalah bentuk pariwisata yang memanfaatkan usaha agro sebagai objek wisata dengan tujuan untuk memperluas pengetahuan, pengalaman, rekreasi, dan hubungan usaha di bidang pertanian. Komponen pengembangan agrowisata dapat berupa flora dan fauna baik yang masih liar, maupun dibudidayakan. Pengembangan agrowisata pesisir ini dapat dilakukan apabila sebuah kawasan memenuhi beberapa syarat sebagai berikut:

1. Memiliki sumberdaya lahan untuk mengembangkan komoditi pertanian yang akan dijadikan sebagai komoditi unggulan.

2. Terdapat prasarana dan infrastruktur yang memadai untuk mendukung pengembangan sistem dan usaha agrowisata, seperti aksesibilitas, saluran irigasi, pusat pengembangan agribisnis.

3. Memiliki sumber daya manusia yang berkemauan dan berpotensi untuk mengembangkan kawasan agrowisata.

4. Pengembangan agrowisata tersebut mampu mendukung upaya-upaya konservasi alam dan lingkungan hidup, dan sosial-budaya.

Beberapa program yang dibentuk oleh kelompok masyarakat memiliki potensi daya tarik wisata yang dapat dikembangkan dalam bidang pengolahan sampah dan budidaya mangrove. Keberadaan acara seni dan budaya lokal juga akan mendukung keberadaan pariwisata di Desa Kersik. Meskipun diketahui bahwa hingga saat ini keberadaan atraksi wisata dan fasilitas penunjang belum sepenuhnya dapat diakses, namun proses pengembangan terus dilakukan pengelola untuk meningkatkan daya tarik masyarakat dalam beberapa strategi. Berikut adalah arahan pengembangan terhadap beberapa daya tarik wisata yang terdapat di Desa Kersik:

\section{a. Program Penanaman Mangrove}

Kawasan hutan mangrove adalah bentuk pariwisata yang memanfaatkan penanaman mangrove sebagai objek wisata dengan tujuan untuk menjaga keseimbangan ekosistem pesisir, memperluas pengalaman dan rekreasi wisatawan, serta mewujudkan hubungan usaha di bidang pertanian. Keberadaan hutan mangrove ini menjadi salah satu program Desa Wisata Kresik yang telah dikembangkan sejak akhir tahun 2020. Program ini dilaksanakan oleh kelompok 
Learning Society: Jurnal CSR, Pendidikan dan Pemberdayaan Masyarakat

Jurnal Program Studi Pendidikan Masyarakat

Universitas Mulawarman

Vol. 2 No. 1, Juni 2021. Hal: 45 - 57

Sahabat Mangrove yang melibatkan 15 orang dan anggota kelompok masyarakat dengan Suport penuh dari PT Pertamina Hulu Kalimantan Timur sebagai penyedia bibitnya. Sahabat Mangrove adalah komunitas yang bergerak di bidang lingkungan yang berfokus pada kelestarian mangrove, pengelolaan pesisir dan laut. Kegiatan Sahabat Mangrove sendiri meliputi rehabilitasi, edukasi, kampanye, pemberdayaan masyarakat dan riset mengenai ekosistem hutan mangrove serta ekosistem pesisir dan laut. Kawasan hutan mangrove menjadi salah satu bagian dari jenis agrowisata pesisir pantai. Tidak hanya menawarkan wisata rekreasi namun juga akan dilakukan pengembangan menjadi wisata edukasi nantinya.

\section{Tabel 1. Arahan Pengembangan Hutan Mangrove}

\begin{tabular}{|c|c|c|}
\hline No & Komponen & Penjabaran \\
\hline 1 & Keunikan & $\begin{array}{l}\text { Pantai Biru Desa Kersik memilik jenis } \\
\text { mangrove yang sangat beragam dan } \\
\text { terbentang di sepanjang pantai. Jenis } \\
\text { mangrove yang paling banyak ditemukan } \\
\text { adalah avecenia dan rizhopora }\end{array}$ \\
\hline 2 & Fasilitas & - \\
\hline 3 & $\begin{array}{ll}\text { Aktivitas } & \text { yang } \\
\text { mungkin } & \\
\text { dikembangkan } & \end{array}$ & $\begin{array}{l}\text { - Penanaman ulang hutan } \\
\text { mangrove yang terkikis oleh } \\
\text { ombak } \\
\text { - Persiapan pembuatan hutan } \\
\text { mangrove yang orientatif pada } \\
\text { ekonomi masyarakat }\end{array}$ \\
\hline 4 & $\begin{array}{l}\text { Arahan } \\
\text { Pengembangan }\end{array}$ & $\begin{array}{ll}\text { - } & \text { Wisata Mangrove } \\
\text { - } & \text { Wisata Edukasi Mangrove } \\
\text { - } & \text { Wisata Fauna Mangrove } \\
\text { - } & \text { Mangrove Center }\end{array}$ \\
\hline
\end{tabular}




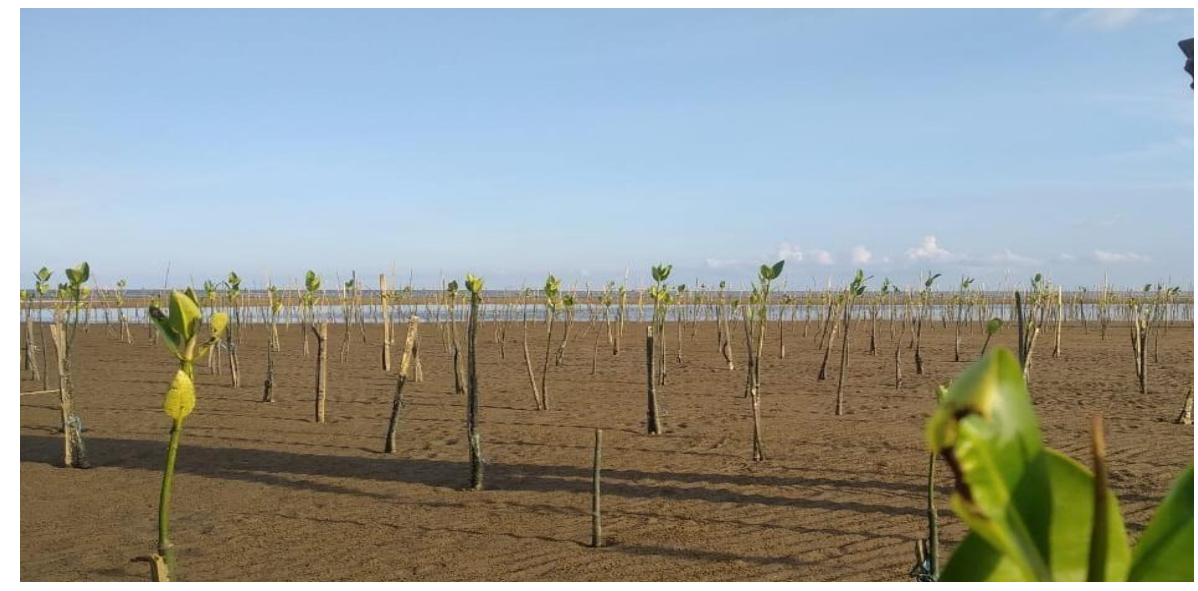

\section{Gambar 1. Kawasan Mangrove Desa Wisata Kersik}

Sumber: Dokumentasi Peneliti

\section{b. Pengembangan Pengelolaan Sampah}

Program pengembangan lain yang

saat ini sedang diupayakan adalah pengelolaan sampah berbasis masyarakat. Kondisi permasalahan sampah di Desa Wisata Kersik banyak dihasilkan dari sampah rumah tangga dan sampah wisatawan di area Pantai Biru Kersik. Ketidaktersediaan mekanisme pengelolaan sampah yang baik menyebabkan pengelolaan sampah berjalan kurang baik. Program yang dilaksanakan oleh masyarakat setempat akan dikembangkan untuk membuat bank sampah di wilayah Desa Kersik. Tidak hanya itu, program ini juga akan mendorong masyarakat sekitar khususnya pengelola untuk benar-benar memilah dan mengolah sampah menjadi barang-barang yang bernilai sehingga layak untuk diperjual belikan. Sejauh ini telah dilakukan sosialisasi pengelolaan sampah oleh Dinas Lingkungan Hidup Kutai Kartanegara. Selain itu, kelompok pengelola sampah juga telahmelakukan visitasi bank sampah di daerah lain untuk belajar bagaimana proses pengelolaan sampah dalam mekanisme bank sampah. Tidak hanya itu, kelompok juga telah mendapatkan pelatihan khusus yang diselenggarakan oleh PT Pertamina Hulu Kalimantan Timur yang bekerjasama dengan pegiat lingkungan Kota Balikpapan dalam mengelola sampah menjadi berbagai macam kerajinan tangan yang bernilai jual. Arah pengelolaan bank sampah dalam konteks desa wisata akan lebih ditekankan pada penyedia produk-produk cindera mata yang nantinya akan diperjual belikan untuk pengunjung wisata Pantai Biru Kersik. Selain itu PT Pertamina Hulu Kalimantan Timur juga menfasilitasi peralatan operasinal untuk bank sampah ssperti mesin pencacah samah, mesin pengurai serabut kelapa dan bak sampah terpilah untuk mendukung opersional bank sampah nantinya. Keberadaan bank sampah ini diharapkan juga mampu mewujudkan Pantai Biru Kersik sebagai destinasi wisata ramah lingkungan kedepannya.

\section{Tabel 2. Arahan Pengembangan Pengolahan Sampah}


Learning Society: Jurnal CSR, Pendidikan dan Pemberdayaan Masyarakat Jurnal Program Studi Pendidikan Masyarakat Universitas Mulawarman

Vol. 2 No. 1, Juni 2021. Hal: 45 - 57

\begin{tabular}{|c|c|c|}
\hline No & Komponen & Penjabaran \\
\hline 1 & Keunikan & $\begin{array}{l}\text { - Satu-satunya bank sampah yang di } \\
\text { kelola dibawah naungan Kelompk } \\
\text { Sadar Wisata Desa. } \\
\text { - Hampir semua anggota adalah } \\
\text { pemuda usia produktif yang belum } \\
\text { memiliki pekerjaan }\end{array}$ \\
\hline 2 & Fasilitas & $\begin{array}{l}\text { Tersedia peralatan operasional seperti mesin } \\
\text { pencacah sampah, mesin cocopeat dan } \\
\text { tempat sampah terpilah yang tersebar di } \\
\text { berbagai area }\end{array}$ \\
\hline 3 & $\begin{array}{ll}\text { Aktivitas } \quad \text { yang } \\
\text { mungkin } & \\
\text { dikembangkan } & \\
\end{array}$ & $\begin{array}{ll}\text { - } & \text { Pelatihan Kreasi Sampah } \\
\text { - } & \text { Mengolah sampah plastik menjadi } \\
\text { kerajinan tangan } \\
\text { - } \\
\text { Mengubah organik menjadi kompos } \\
\text { dan cocopeat }\end{array}$ \\
\hline 4 & \begin{tabular}{|l|} 
Arahan \\
Pengembangan
\end{tabular} & $\begin{array}{l}\text { - Bank sampah akan mendukung } \\
\text { Pantai Biru Kersik menjadi pantai } \\
\text { yang ramah lingkungan } \\
\text { - Menjadi pelopor penggunaaan } \\
\text { biodegreble pengganti plastic } \\
\text { - Menjadi pelopor produksi cocofiber } \\
\text { sebagai bahan oil absorban } \\
\text { - Sebagai salah satu pemasok } \\
\text { souvenir khas pantai Biru Kersik } \\
\text { - Menjadi Bank sampah yang turut } \\
\text { serta meningkatkan taraf hidup } \\
\text { masyarakat baik secara ekonmi dan } \\
\text { lingkungan }\end{array}$ \\
\hline
\end{tabular}



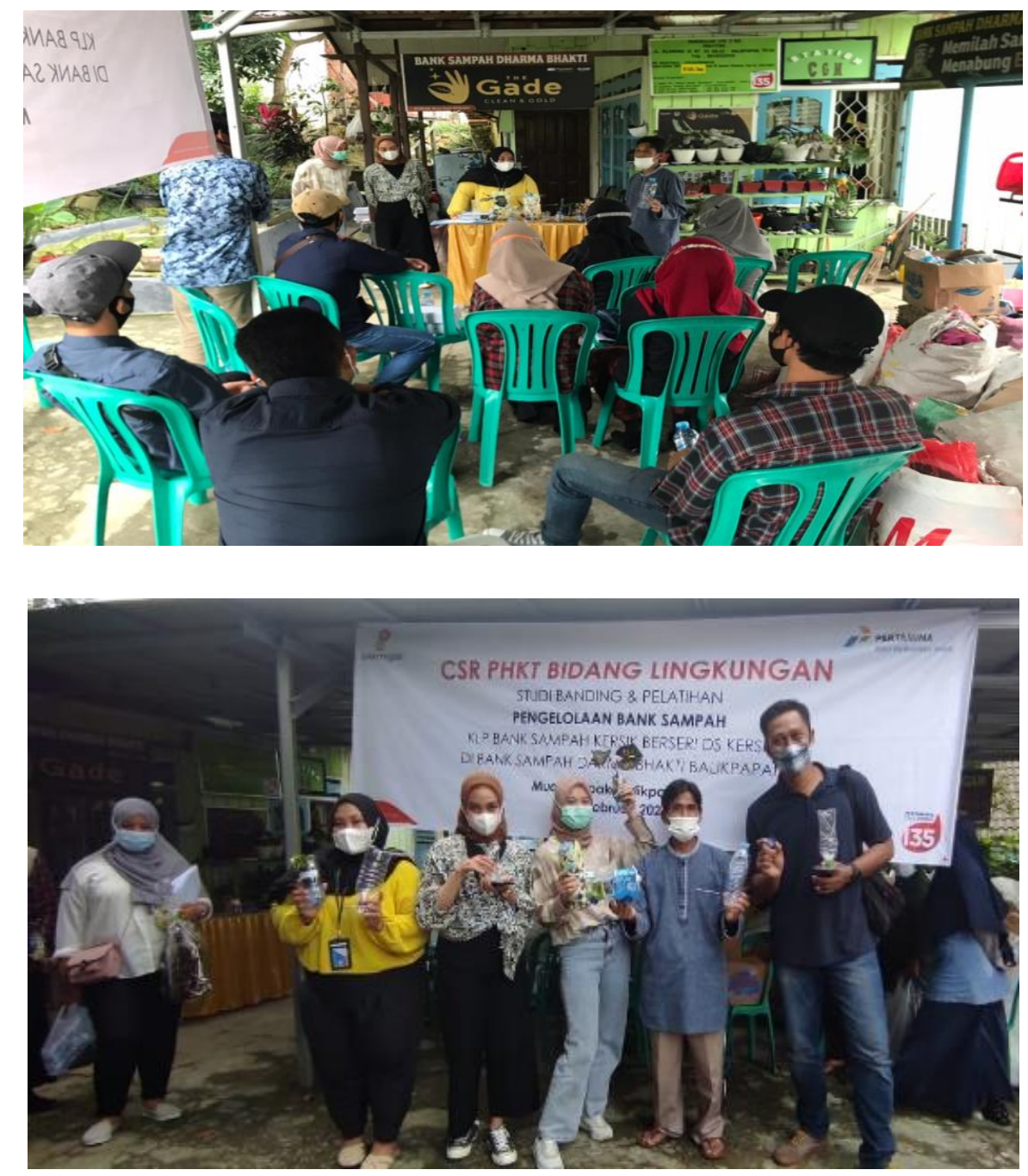

\section{Gambar 2. Studi Banding dan Pelatihan Pengelolaan Sampah}

\section{Sumber: Dokumentasi Peneliti}

\section{c. Atraksi Kreasi Budaya Lokal}

Pagelaran kreasi budaya menjadi salah satu acara tahunan yang diselenggarakan di Pantai Biru Kersik. Keberadaan acara ini masih sangat diminati oleh pengunjung. Acara yang digelar setiap tahun sekali ini banyak ditunggu oleh masyarakat sekitar maupun masyarakat luar Desa Kersik. Terdapat banyak tampilan budaya tradisional yang dikemas dalam berbagai tarian, pertunjukan musik, seni bela diri, hingga sajian kuliner daerah. Pagelaran ini pada umumnya diselenggarakan oleh kelompok pemuda sekitar bekerja sama dengan pemerintah desa setempat. Dengan adanya pagelaran ini dinilai mampu meningkatkan daya tarik wisatawan, oleh sebab itu dibutuhkan arahan pengembangan agar pagelaran selalu memberikan kesan yang berbeda setiap tahunnya. Hal ini penting untung dilakukan guna mempertahankan minat wisatawan untuk berkunjung ke Desa Wisata Kersik. 
Learning Society: Jurnal CSR, Pendidikan dan Pemberdayaan Masyarakat Jurnal Program Studi Pendidikan Masyarakat Universitas Mulawarman

Vol. 2 No. 1, Juni 2021. Hal: 45 - 57

Tabel 3. Arahan Pengembangan Pagelaran Kreasi Budaya

\begin{tabular}{|c|c|c|}
\hline No & Komponen & Penjabaran \\
\hline 1 & Keunikan & $\begin{array}{l}\text { - Pertunjukan tarian tradisional dg } \\
\text { keanekaragaman suku dan } \\
\text { budaya } \\
\text { - Pertunjukan seni bela diri dan } \\
\text { akustik dari para pemuda } \\
\text { - Tampilan kuliner dari menu } \\
\text { seafood khas pesisir }\end{array}$ \\
\hline 2 & Fasilitas & $\begin{array}{ll}\text { - } & \text { Gazebo untuk penonton } \\
\text { - } & \text { Toilet mushola } \\
\text { - } & \text { Hamparan pasir pantai yang luas } \\
& \text { untuk pertunjukan }\end{array}$ \\
\hline 3 & $\begin{array}{ll}\text { Aktivitas } & \text { yang } \\
\text { mungkin } & \\
\text { dikembangkan } & \end{array}$ & $\begin{array}{l}\text { - Menghidupkan kembali sanggar } \\
\text { tari yang ada di daerah pesisir } \\
\text { pantai Biru Kersik } \\
\text { - UMKM masyarakat pesisir } \\
\text { dikelola dengam baik dan } \\
\text { ditampilkan di setiap event akan } \\
\text { menjadi nilai jual untuk para } \\
\text { pelaku usaha serta menjadi oleh- } \\
\text { oleh khas yang dapat dibawa } \\
\text { pulang oleh para wisatawan } \\
\text { - Penghijauan kembali di } \\
\text { sepanjang bibir pantai agar } \\
\text { semakin sejuk dan wisatawan } \\
\text { semakin nyaman saat berpiknik } \\
\text { dan menyaksikan pertunjukan }\end{array}$ \\
\hline 4 & $\begin{array}{l}\text { Arahan } \\
\text { Pengembangan }\end{array}$ & $\begin{array}{l}\text { Menghidupkan kembali festival } \\
\text { event budaya, karena dengan } \\
\text { adanya event di setiap tahun } \\
\text { dapat menjadi daya tarik } \\
\text { tersendiri dimana didalam event } \\
\text { tersebut aneka budaya, kuliner } \\
\text { serta perlombaan tradisional bisa } \\
\text { ditampilkan sekaligus } \\
\text { mendongkrak ekonomi para }\end{array}$ \\
\hline
\end{tabular}




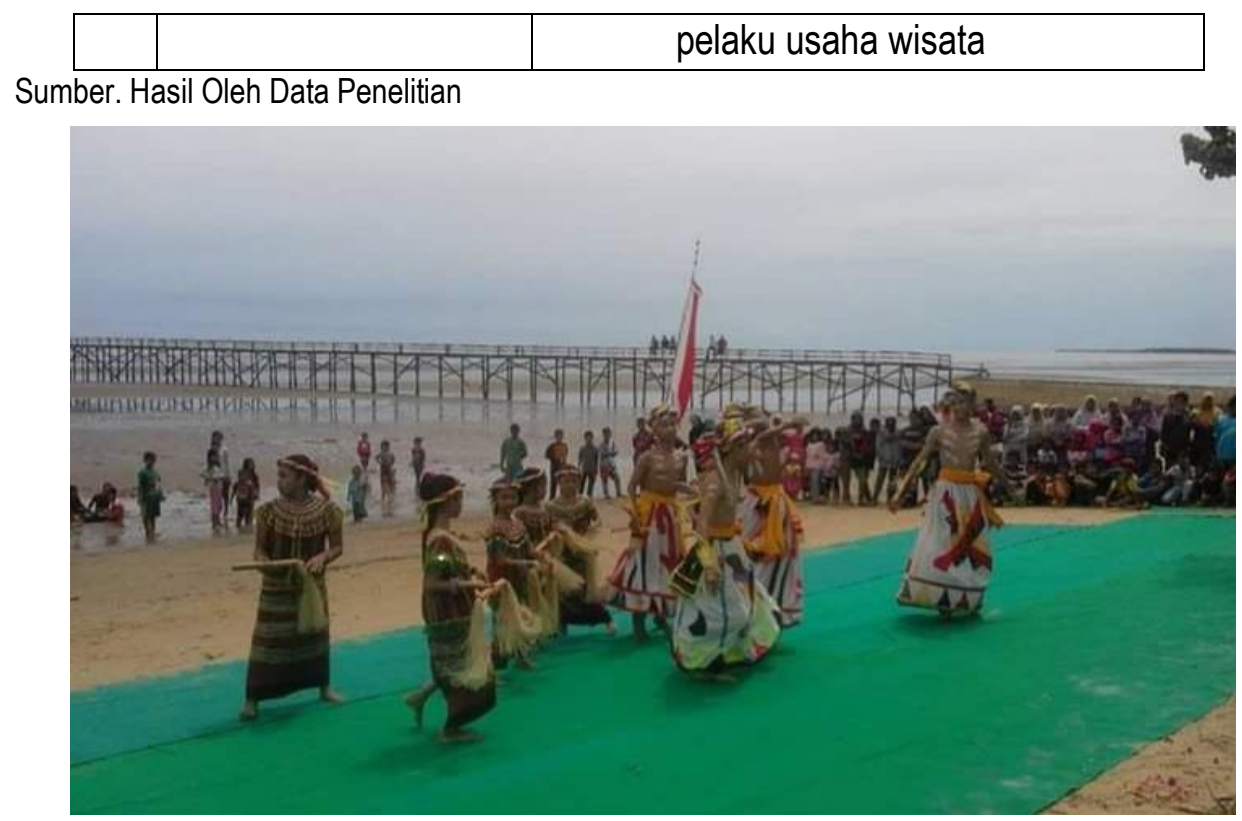

\section{Gambar 3. Salah Satu Tarian yang ditampilkan saat event Kreasi Budaya di Pantai Biru Kersik} Sumber Dokumentasi Peneliti

2. Aspek Sosial, Ekononmi, dan Lingkungan Pengembangan Desa Wisata Kersik

Pengembangan industri pariwisata dinilai sebagai salah satu bidang usaha yang mampu menghasilkan multiplier effect yang tinggi. Dampak yang diharapkan dari adanya suatu pengembangan pariwisata adalah peningkatan sumber daya manusia baik dalam bidang pendidikan, ekonomi, sosial, dan lingkungan. Peningkatan sumber daya manusia dalam bidang pendidikan yang dipengaruhi oleh industri pariwisata dapat diwujudkan melalui wisata edukasi yang telah banyak dikembangkan di berbagai tempat, salah satunya di Desa Wisata Kersik. Peningkatan sumber daya manusia dalam bidang ekonomi dapat dilihat dalam peningkatan pendapatan masyarakat yang dipengaruhi oleh kegiatan pariwisata. Secara lebih luas peningkatan dalam bidang ekonomi juga bisa dilihat dari adanya peluang usaha baru, pembukaan lapangan kerja, serta meningkatnya kesempatan kerja bagi masyarakat lokal. Pada bidang sosial, peningkatan sumber daya manusia dapat dilihat dari pengayaan pengalaman yang didapatkan dari adanya interaksi dengan wisatawan, baik wisatawan lokal maupun wisatawan luar. Sedangkan dalam bidang lingkungan, meningkatnya kesadaran masyarakat dalam menjaga keseimbangan lingkungan dengan cara menjaga kebersihan dan merawat lingkungan yang dipergunakan untuk kegiatan pariwisata.

Sebagai salah satu kegiatan usaha yang melibatkan masyarakat secara langsung, keberadaan industri pariwisata di lingkup daerah seperti Desa Wisata Kersik tentunya akan membuat masyarakat setempat mengalami banyak perubahan. Sebab dengan dikembangkannya desa wisata maka artinya 
Learning Society: Jurnal CSR, Pendidikan dan Pemberdayaan Masyarakat

Jurnal Program Studi Pendidikan Masyarakat

Universitas Mulawarman

Vol. 2 No. 1, Juni 2021. Hal: 45 - 57

masyarakat setempat membuka kesempatan yang seluas-luasnya untuk masyarakat luar datang ke lingkungan tempat tinggal mereka. Hasil dari interaksi yang masyarakat lakukan tentunya akan mengubah gaya hidup dan mempengaruhi upaya mereka dalam memenuhi kebutuhan sehari-hari. Sebelum menjadi desa wisata, Desa Kersik merupakan desa pesisir yang mayoritas masyarakatnya bekerja sebagai nelayan. Kehidupan bermasyarakat di Desa Kersik cukup baik, hal ini dapat dilihat dari adanya beberapa kegiatan atau pertemuan dari sejumlah anggota kelompok masyarakat. Artinya, masyarakat masih memegang teguh modal sosial yang dimilikinya. Masyarakat yang awalnya hanya mengandalkan pendapatan dari satu sektor kini memiliki peluang untuk mengembangkan usaha di bidang pariwisata. Berikut adalah beberapa dampak pengembangan pariwisata Desa Wisata Kersik dalam beberapa aspek:

1). Berkurangnya permasalahan abrasi oleh air laut

Penanaman mangrove yang dilakukan oleh kelompok masyarakat setempat memberikan dampak positif bagi lingkungan pesisir. Berkurangnya tingkat abrasi di Pantai Desa Kersik salah satunya disebabkan karena penanaman ribuan mangrove oleh masyarakat.

2). Terwujudnya pengelolaan sampah melalui Bank Sampah

Mekanisme pengelolaan sampah belum berlangsung secara optimal karena keterbatasan bank sampah yang masih dalam tahap pembangunan. Meski demikian kelompok pengelola sampah Desa Kersik telah memahami sistem bank sampah dengan melakukan studi kunjungan kepada bank sampah daerah lain yang telah beroperasi. Selain itu kelompok juga telah mendapatkan pengetahuan untuk mengolah sampah menjadi barang bernilai jual. Sehingga dari aspek persiapannya hanya menunggu ketersediaan bank sampah di Desa Kersik.

3). Pelestarian Budaya dan Kesenian Tradisional

Melalui pagelaran kreasi seni dan budaya tahunan maka kesenian budaya daerah atau lokal akan rutin digelar. Hal ini menjadi bentuk upaya pelestarian budaya oleh masyarakat setempat agar generasi muda juga turut melestarikannya. Selain itu acara ini juga menjadi salah satu strategi promosi pariwisata yang terdapat di Desa Kersik. Salah satu jenis tampilan yang paling banyak diminati adalah tari-tarian, karena menampilkan tarian dari berbagai daerah dengan gerakan yang cantik dan kostum yang unik, serta tidak jarang dimodifikasi dengan tarian modern sehingga membuatnya lebih menarik untuk disaksikan oleh para penonton.

4). Menigkatkan perekonomian masyarakat

Pengembangan Desa Wisata Kersik tentunya juga memberikan peluang bagi masyarakat setempat untuk 
Learning Society: Jurnal CSR, Pendidikan dan Pemberdayaan Masyarakat

Jurnal Program Studi Pendidikan Masyarakat

Universitas Mulawarman

Vol. 2 No. 1, Juni 2021. Hal: 45 - 57

membuka jenis usaha baru baik dibidang produk maupun jasa pariwisata. Selain itu juga membuka kesempatan untuk mendapatkan lapangan pekerjaan baru dalam beberapa program yang saat ini sedang dilaksanakan baik di kawasan mangrove maupun pengelolaan sampah.

\section{KESIMPULAN}

Kawasan Desa Wisata Kersik
memiliki potensi wisata dalam mengembangkan agrowisata pesisir. Strategi pengembangan dibentuk dalam dua program pemberdayaan yang sekaligus dilaksanakan untuk mengatasi permasalahan yang terjadi di Desa Kersik. Program budidaya mangrove selain berhasil mengatasi permasalahan abrasi juga menjadi potensi wisata edukasi yang dapat dikembangkan untuk melengkapi pilihan wisata di Pantai Biru Kersik. Sementara itu, keberadaan program pengelolaan sampah juga menjadi solusi dari permasalahan pencemaran sampah di Desa Kersik. Kedepannya pun pengelolaan sampah akan didorong sebagai media penghasil produk cindera mata yang dapat dinikmati oleh pengunjung. Penentuan program pemberdayaan ini dinilai efektif dan relevan, sebab selain bersifat solutif juga menghasilkan berbagai arahan pengembangan yang tentunya mendukung upaya pembentukan Desa Wisata Kersik yang lebih baik.

\section{DAFTAR PUSTAKA}

Asker, S. dkk. (2010). Effective Community Based Tourism: A Best Practice
Manual. Australia: Sustainable

Tourism Cooperative Research Centre

Aprilia, Dita. (2020). Analisis Penerapan

Prinsip Community Based

Tourismpada Homestay Balkondes

Wanurejo. Skripsi: Universitas Gadjah Mada

Moelong, L. J. (2012). Metodologi Penelitian Kualitatif. Bandung: PT Remaja Rosdakarya.

Pramusita, Arina dan Sarinastiti, Eska N. (2018). Aspek Sosial Ekonomi Masyarakat LOkal dalam Pengelolaan Desa Wisata Pantai Trisik, Kulonprogo. Jurnal Pariwisata, 2 (1): 14-25.

Rizkianto, N., dan Topowijono. (2018). Penerapan Konsep Community Based Tourism Dalam Pengelolaan Daya Tarik Wisata Berkelanjutan (Studi Pada Desa Wisata Bangun, Kecamatan Munjungan, Kabupaten Trenggalek). Jurnal Administrasi Bisnis, 58(2), 20-26.

Utama, I.G.B.Rai. (2009). Agrowisata sebagai Pariwisata Alternatif. Diakses dari

www.gdnet.org/CMS/fulltext/1164925 881_Buu_Agrowisata.doc 